\title{
Õigeusu kese eestikeelse õigeuskliku silmis: ühe kvalitatiivse uuringu tulemused $^{1}$
}

\begin{abstract}
Liina Eek
Teesid: Artiklis kirjeldatakse, mida peavad eesti keelt kõnelevad õigeusklikud õigeusu keskme kõige olulisemateks aspektideks. Tulemused on saadud religioonisotsioloogilise uuringu käigus. Artiklis on hulgaliselt tsitaate intervjuudest selle kohta, mis teeb õigeusu inimeste silmis eriliseks ja teistest konfessioonidest eristuvaks. Vastuste kategoriseerimisel on kasutatud Ninian Smarti religiooni dimensioonide klassifikatsiooni. Tulemustes ei eristunud ükski tüüpiline aspekt, mida enamik eestikeelseid õigeusklikke näeksid olevat õigeusu keskmes. Välja toodi erinevaid olulisi aspekte ning uuringus mainiti kõiki seitset religiooni dimensiooni, kuigi mitte võrdsel määral. Enim esindatud olid kogemuslik ja emotsionaalne ning rituaalne dimensioon, kuid mainiti ka materiaalset ja filosoofilist. Artiklis vaadeldakse ka arvamuse kujunemist õigeusu kohta, selle seost religioosse identiteediga ning teistele konfessioonidele vastandumise rolli selles.

Märksõnad: kvalitatiivne uurimismeetod, religiooni dimensioonid, religioosne identiteet, vastandumine, õigeusk Eestis
\end{abstract}

\section{Sissejuhatus}

Mõnel inimesel on kirikusse kuulumine seotud perekonna traditsiooniga, teisel on see pika otsingu teel leitud vastus eksistentsiaalsetele küsimustele, kolmandat on usk tabanud kui ilmutus mingi müstilise kogemusena. Selles artiklis püüan välja selgitada, mis köidab inimesi õigeusu kirikus, mis tundub neile õigeusus kõige olulisem. Et seda teada saada, küsitlesin end õigeusklikuna määratlevaid inimesi ${ }^{2}$ ja püüdsin nende vastuste abil leida aspekte, mida nähakse õigeusu keskmes olevat. Lisaks selgus uuringu käigus, kuidas ja millele tuginedes on inimesed kujundanud oma arvamuse õigeusust.

Õigeusku, mille keset ma otsisin, võtan kõige laiemas tähenduses. Mõned uurijad teevad vahet religioonil (antud juhul õigeusul) ja religioossusel (individuaalsel usul; vt sarnane lähenemine Geertz 1993). Religioossus tähistab siin eelistusi, emotsioone, uskumusi ja tegevusi seoses religiooniga (Stolz 
2009: 347), religioon aga kultuurilist sümbolite süsteemi, olles kultuuriline nähtus. Sellisest kaksikjaotusest (religioon ja religioossus) jäävad välja religioossed institutsioonid (kirikud, kogudused jne), mida mina antud uurimuses hõlmasin õigeusu mõiste alla. Seega koosneb õigeusk selle artikli tähenduses nii institutsionaalsest kui ka individuaalsest poolest. Et hõlbustada vastuste süstematiseerimist, lähtusin Ninian Smarti klassikalisest klassifikatsioonist, mille järgi võib religioonis (sensu lato) eristada seitset aspekti ehk dimensiooni (Smart 1996: 10-11; 1998: 13-21).

1. Praktiline ja rituaalne dimensioon, mis hõlmab religioosseid rituaale, jumalateenistuse korda, palveelu, salasuste (sakramentide) läbiviimise korda, kiriku traditsioone jms.

2. Kogemuslik ja emotsionaalne dimensioon. Siia kuulub religiooni subjektiivne ja emotsionaalne pool, see, mis toimub inimese sees.

3. Narratiivne või müütiline dimensioon. Siia kuuluvad õigeusu jutustused, nii müütilised kui ajaloolised, nii Jeesuse elulugu, loomislugu, eshatoloogia kui ka dokumenteeritult toimunud sündmused, näiteks pühakute elulood. See aspekt on tihedalt seotud rituaalse poolega, nt jumalateenistuse käigus meenutatakse mitmeid narratiive.

4. Doktriin ja filosoofiline dimensioon hõlmab religiooni intellektuaalset komponenti, teoloogiat, mis selgitab Jumala olemust, loomislugu ja muid eksistentsiaalseid küsimusi.

5. Eetiline ja õiguslik dimensioon, mille alla paigutatakse religiooni eetilised ja käitumuslikud juhised ning väärtushinnangud, mis on seotud kiriku õpetusega. Siia kuulub kristlik eetika, mille keskmes on armastus.

6. Sotsiaalne ja institutsionaalne (organisatoorne) dimensioon, mis puudutab kiriku ja tema hierarhia organiseeritust ning suhtestumist koguduse ja ümbritseva ühiskonnaga, selle alla paigutatakse ka kiriku töökorraldus, preestrid, kloostrid (munklus) jne.

7. Materiaalne dimensioon, religiooni väline avaldumisviis, mille alla kuuluvad kirikuhooned, nende arhitektuur ja interjöör, rituaalsed objektid, ikoonid jm.

See, kuidas inimesed õigeusku mõistavad ja mis aspektid tunduvad neile seal olulised, on tihedalt seotud inimese religioosse identiteediga. Identiteedi loomise protsess on väidetavasti kõige vähem mõistetud kontseptsioon üldse (Hall 1996: 16), kuigi sellest on palju kirjutatud. Religioosse identiteedi loomisel on teatud seaduspärad ja meetodid, mida ma kirjeldan lähemalt oma tulemuste valguses diskussiooniosas. 


\section{Materjal ja metoodika}

Originaalmaterjali kogusin aastatel 2012-2014, intervjueerides õigeusu kiriku (nii Eesti Apostlik-Õigeusu Kiriku, edaspidi EAÕK, kui ka Moskva Patriarhaadi Eesti Õigeusu Kiriku, edaspidi MP EÕK) 57 eesti keelt kõnelevat vaimulikku ja koguduse liiget. Intervjueeritutest 21 olid vaimulikud (intervjuu järel märge V), lisaks 28 naist $(\mathrm{N})$ ja 8 meest $(\mathrm{M})$ vanuses $22-89$ aastat. Vaimulike anonüümsuse tagamiseks on nende vanus artiklis toodud 10aastase vahemiku täpsusega.

Andmed kogusin poolstruktureeritud küsimustiku abil informante intervjueerides. Siin artiklis toodud andmed on osa pikemast küsimustikust ja sisaldavad vastuseid küsimusele, kuidas informandid enda jaoks õigeusku mõtestavad, mis on nende jaoks kõige olulisemad aspektid, mis moodustavad nende silmis õigeusu keskme ja mis eristab õigeusku teistest konfessioonidest. Siin ei lähtunud ma kiriku õpetusest ja tõekspidamistest, vaid sellest, mis subjektiivselt inimesele kõige olulisem tundus.

Andmeid analüüsisin kvalitatiivse sisuanalüüsi abil. Tulemused kategoriseerisin, kasutades kombineeritult deduktiivset ja induktiivset meetodit. Kuna tegu on kvalitatiivse uuringuga, saan selle alusel teha üldistusi selle kohta, milliseid arusaamu esineb selle teemaga seoses eesti keelt kõnelevate õigeusklike seas, kuid ma ei saa teada, millised on levinumad ja millised vähemlevinud arusaamad. Kvalitatiivse analüüsi tegemise puhul on minimaalne piisav informantide arv 12-15 (Guest et al 2006: 59-60; Bertaux 1981: 29-45) ning erinevad uurijad soovitavad kasutada 30-60 informanti (Bernard 2000: 178; Morse 1994: 225), sõltuvalt teema keerukusest ja vastuste varieeruvusest. Minu andmestik küllastus enne 60ni jõudmist ja ma eeldan, et minu valimis on esindatud kõik enamlevinud vastusevariandid.

\section{Tulemused}

Küsimusele, mis on õigeusu keskmes, ei osatud sageli vastata. Eriti olid kimbatuses inimesed, kes olid sinna kirikusse sattunud perekonna kaudu ega olnud kunagi pidanud tegema valikuid või kaaluma, kas see kirik sobib neile või mitte. Nendel, kes olid ise leidnud tee kirikusse (otsijad, pöördujad), tundus see küsimus olevat rohkem läbi mõeldud. Õigeusu kesksete aspektidena toodi välja väga erinevaid nähtusi alates välisest kullast-karrast ja lõhnadest kuni sügavate teoloogiliste põhjusteni. Enamasti nimetati rohkem kui ühte aspekti, ja mõnda inimest võis õigeusu kirikus köita samaaegselt nii ikoonide kuld kui ka apofaatiline mõtteviis ${ }^{4}$, nii palveelu kui ka oikonoomia ${ }^{5}$. 
Allpool kirjeldan, milliseid õigeusu keskmes olevaid aspekte inimesed oma intervjuudes välja tõid. Kategooriad ei ole üksteist välistavad ja on sageli kattuvad. Aspektid ei ole toodud ei esinemissageduse ega olulisuse järjekorras.

\section{Materiaalne dimensioon: kiriku väline külg, ikoonid}

Ühe aspektina, mis inimesi õigeusu kirikus köidab ja ilma milleta nad õigeusku ette ei kujuta, toodi välja kiriku väline ilu. Õigeusu kirikus pälvib esimesena tähelepanu kiriku väline rikkalikkus ning viiruki ja vahaküünalde lõhn. Võrreldes enamiku teiste Eestis tegutsevate konfessioonide kirikutega on õigeusu kirik väga ohtralt kaunistatud. See toob inimese argipäevast välja, tekitab erilise tunde ning on otseselt seotud ka emotsionaalse dimensiooniga.

Mulle meeldib viiruk, kü̈̈lavalgus, visuaalne [külg], väljapool argipäeva olek, meeldivad ikoonid. See töötab koos. Õigeusu kirik kõnetab su meeli, lõhnad, silmad, kuulmist (N 42).

Kogu see väline hiilgus tekitab selle õige tunde. [---] Õigeusu kirik on soe. Vist ei tohi olla kõige olulisem väline külg ja hiilgus, aga minu jaoks nii on, ma saan olla seal nagu transis, ma olen oma elemendis. Kiriku ilu on oluline (M 32).

Õigeusu kiriku välise külje juurde kuuluvad lahutamatult ikoonid, mis on "südantkosutavalt vanamoelised" - õigeusu kirik ei lase end moest ega muudatustest mõjutada, ikoonide maalimise reeglid on rangelt paigas. Ka kirikute sisekujundus on sarnane, moderniseerumist välditakse. Inimene tunnetab selles kaasajast puudutamata interjööris teatavat arhailisust, mis sisendab usaldusväärsust.

Mulle meeldib ka väline külg, ikoonid, vahaküünalde lõhn, mingisugune vanamoodsus. See on kosutav. Sa tajud seda arhailisust. See lisab jõudu, tugevust, [tunned,] et samu küsimusi on lahendatud juba tuhandeid aastaid tagasi ( $\mathrm{N} 48$ ).

Viimases tsitaadis toonitatud arhailisus toob sisse järgmise aspekti - kiriku ajaloo ja narratiivid. 


\section{Narratiivne dimensioon}

\section{Kiriku ajalugu}

Siia kuulub nii narratiiv kiriku ajaloost, mis läheb tagasi apostlite aega, kui ka dokumenteeritud jutustus kiriku ajaloost. Ajalooline aspekt on oluline kahest küljest. Esiteks tunnetatakse õigeusku kui kõige algsemat kirikut, mis on apostlite ajast saadik olnud muutumatu. Teiseks avaldab muljet õigeusu levitamise rahumeelne viis. Kui räägiti algupärasusest ja järjepidevusest (sama teema tuleb sisse ka praktilise ja rituaalse dimensiooni juures, vt allpool), siis kasutati sageli allika ja jõe metafoori - õigeusu kirik kui allikas, kust kristluse jõgi alguse saab.

Miks ma peaksin jooma sellest jõest, mis on suubunud just merre, kui mul on kõik võimed ja võimekus olemas, et ma saan juua seda puhast ja allikast tulevat [vett]? Kui mul on valida, miks ma peaksin jooma seda, mis võib mind kahjustada, kui ma saan juua allikast? Selles kontekstis jõudsingi ma allikani [õigeusu kirikuni] (V 40-50).

Mitme informandi silmis oli oluline õigeusu ajalugu, viis, kuidas ta on maale saabunud ning kuidas teda on levitatud.

Minu jaoks on õigeusu kirikul ka see tugevus, et õigeusk tuli Eestisse rahumeelsel moel. Ei jõudnud siia Venemaalt, vaid Bütsants - Ukraina ja siis jõudis Setomaale. Ükski kroonik ei kirjuta, et oleks olnud mingisuguseid konflikte. Mis puudutab kohalikku usundit, need sulandusid probleemideta (V 40-50).

Viimasest tsitaadist tuleb sisse "mõõga ja vere" teema. Õigeusu saabumisest Eestisse ei ole kuigi palju teada, aga arvatavasti jõudis ta siia tõepoolest rahumeelsemalt kui toonane katoliiklus. Usk sellesse tuli välja iseäranis setude ${ }^{6}$ intervjuudest, mida illustreerib alljärgnev tsitaat.

Meie [setud] olime vaba rahvas, meid ei pekstud. Luter(lus) toodigi sisse sakslaste, ordu poolt orjade jaoks, kuidas see neile pähe ei jõua? Vene usk on siin ajalooliselt olnud. Oluline, et see pole sunnitud usk (M 48).

Eelnev informant nimetas õigeusku "vene usuks", kuigi Setumaal on EAÕK kogudused. Õigeusku nimetasid vene usuks ka mitmed inimesed, kes olid kirikuga liitunud enne EAÕK autonoomia taaskehtestamist, kuid see nimetus ei kandnud endas üldjuhul poliitilist varjundit. Vastandina sellele räägib järgmine informant, kuidas ta liitus kirikuga just sellepärast, et õigeusk ei ole "vene usk" ja kirikuga liitumist soodustas teadmine, et õigeusk ei ole algselt pärit 
mitte Venemaalt, vaid hoopis Bütsantsist, nagu tõid välja ka eespool tsiteeritud informandid.

Olin [enne ristimist, vähem kui aasta enne intervjuud 2013 suvel] sügava eelarvamusega õigeusu suhtes, nõuka-aegne õpetus oli mind täiesti pimestanud. Eelmisel aastal alles sain teada, et meie eesti õigeusk on täiesti vaba ja iseseisev ja õigeusk pole üldse Venemaalt pärit. Luteri kirik on meil siin [tegu väikse maakohaga Eestis] kesine, seal õieti midagi ei toimu, siis rõõmuga otsustasin õigeusu kiriku kasuks. Ka tänu [oma preestrile N] sain teada, et see on meie ainuke sõltumatu ja iseseisev usk ja kõik teised usud on õigeusust pärit. Ajalooline aspekt oluline. Otsin algupärast (M 44).

Rahumeelse misjoni ja pika rahumeelse ajaloo olulisust mainisid ka mõned informandid, kes olid õigeusu kirikuga liitunud väljaspool Eestit, maades, kus õigeusk on olnud traditsiooniline (riigi)usk juba enam kui tuhat aastat.

\section{Palve- ja laulutekstid}

Paljud informandid tõid välja vanade tekstide ja seal peituva sõnumi olulisuse. Õigeusus palvetatakse traditsiooniliselt vanade palvetekstide järgi, jumalateenistusel ja palvustel loetavad tekstid ei ole oluliselt kaasajastatud ja kõlavad vanamoodsatena. Paljud informandid kirjeldasid, et esmapilgul tuimade ja naiivsete palvetekstide lugemine muudab neis midagi olemuslikku. Mulle kirjeldati, kuidas ühe ja sama teksti "endast läbi laskmisel” hakkab tekst järsku kõnelema ja kinnitati, kui oluline on palvetada vanade palvetekstide järgi.

[---] protestantlikke kirikuid iseloomustab veel see, et nö ei palvetata palvete järgi, mis on aastasadu ja võibolla tuhandeid formeerunud, vaid põhimõtteliselt palvetatakse peast, kuidas sul parajasti on [mõtted ja sõnad peas]. Muidugi siis see, kui sa oled harjunud ainult paberilt palvetama, see võib ühel hetkel ära surmata su võimekuse üldse midagi oma sõnadega ütelda, see on oht küll. Aga luterlus ei tunne sellist [reeglit, et palveid loetakse raamatust]. Näiteks kui sa üksi palvetad, siis on väga ebatavaline, et loetakse kaanoneid või kirjutatud palveid, ja sa loed neid nagu oma palveid. Mulle tundub see väga ahistav, et sellist võimalust pole, mitte et mul luterlasena see keelatud oleks, aga keegi üldse ei avarda mu maailma, sest traditsioon on hoopis teine (N 37).

Sarnast fenomeni kirjeldati laulutekstide puhul, kus laulutekstis sisalduv sõnum annab vastused elulistele küsimustele. 
Ma käisin ka seal [metodisti kirikus] ja mulle meeldis seal kõik [---], aga mulle oudselt ei meeldinud meloodiad. Muusika on minu jaoks niivõrd oluline, et mind see meloodiate tühisus [häiris], või need meloodiad veel vahel kandsid, aga sõnumi tühisus või sõnumi lapselikkus [---] oli tollel hetkel mulle täiesti vastumeelt. [Praegu, õigeusu kirikus] ma olen nii magusa meloodia ja nii magusa sõnumi sees, et ma saan kõigest muust ka aru, see on mulle ära seletatud nende meloodiatega, nende sõnumitega, mis õigeusus on (N 41).

\section{Praktiline ja rituaalne dimensioon: rituaalide muutumatus, algupärasus}

Õigeusu kirikus ei ole olnud ühtki suurt reformi (väiksemad reformimised ja muutused välja arvata), rituaalid ning jumalateenistuse kord on püsinud ajaloos suhteliselt muutumatutena. See annab inimestele teatava turvatunde, muutumatus ja algupärasus oleksid justkui usaldusväärsuse ja autentsuse garantiiks. Paljud informandid rõhutasid, kuidas neile meeldib see, et jumalateenistus on alati sarnane, sõltumata kirikust.

[Mulle meeldib] see, et meil on suurepärased traditsioonid, liturgiad, mis on meile pärandatud, kõik kokku. Traditsioon on ühtne, kuigi erinevates piirkondades natuke erinevalt arenenud. Ikka sama liturgia, sama traditsioon, ka nendel, kes Halkedonist ${ }^{7}$ kõrvale jäänud. Sisulist vahet ju pole. [---] Isegi Armeenia kirikus, ka neil on liturgia sama (V 40-50).

Traditsioonide muutumatus ja teadmine jumalateenistuse korrast aitab inimestel süveneda ja keskenduda palvetamisele.

Mis mind võlub õigeusu liturgia juures, on see, et ükskõik, mis kirikusse ma lähen, ma tean täpselt, mis juhtub, mind ei ehmatata mingi õudusega, et keegi ei roni ülestõusmispühade öösel kitarriga altarisse ja ei hakka selle saatel Vana Testamenti laulma. Ma lähen kirikusse ja ma saan keskenduda seal sellele, milleks ma olen sinna tulnud - ma saan Jumalat kiita, ma saan ennast avada mingile muule asjale. [---] Traditsioonide järjepidevus oluline, euharistiline liturgia on kiriku keskmes, see kannab kirikut, ja see ei saa olla improvisatsioon, et täna teeme nii ja homme naa ja eile tegime hoopis kolmandat moodi (N 43).

Traditsioonide muutumatust hindavad ka nooremad inimesed, kes ei oska hästi sõnastada, mis neile õigeusu kirikus meeldib, aga nad tunnetavad, et liturgia 
muutumatus on neile meelepärane ja teeb olemise koduseks, nagu seda väljendas üks noor informant.

Õigeusu kirikus on tuttav ôhustik, selline mõnus (M 22).

Traditsioonide ja järjepidevuse olulisust tõid eriti sageli välja vaimulikud, kuigi ka ilmikutele olid need aspektid olulised. Samas leiti, et õigeusu kirik pole täiesti kivistunud: väiksemaid muutusi tehakse ikka, ning see hoiab kiriku elava ja kaasajastatuna.

Õigeusk on terviklik, traditsiooniline, järjepidevust omav kristlus. Kõik, mis elab, muutub, aga ma usun, et järjepidevusel on olulisus. Traditsioon on see, mis sisu alles hoiab, seda ei leita pidevate revolutsioonide kau$d u$. Traditsioon on nagu suur jõgi, kus see algne vesi voolab, aga kaasa haaratud on ka igasugu rämpsu. Ka õigeusus uuendatakse ka, teatud kriitilisus on olemas, vigasid kõrvaldatakse (V 40-50).

Õigeusu kiriku rõhutatud kogemuslikkus on olnud alati minu jaoks väga tähtis ja [---] õigeusu kirik [ei ole] mitte ratsionaalse mõtlemise tagajärjel visanud oma pärandist last pesuveega välja. See on võimaldanud säilitada palju esivanemate tarkusi, mis otseselt polegi kiriklikud, aga mis on intiimselt perekesksed, ja sellega tekitavad turvatunde. Õigeusu kirik ei lähe igasuguse moeröögatusega kaasa. Samas pole ka ta vana muuseum (V 40-50).

\section{Doktriin ja filosoofiline dimensioon}

\section{Teoloogia, selle täiuslikkus, kõikehõlmavus}

Õigeusus ei seisa intellektuaalne komponent täiesti eraldi, sellega on lahutamatult seotud praktiline ja emotsionaalne dimensioon. Jumalani ei jõuta pelgalt intellektuaalsete mõtiskluste kaudu, vaid selleks on vaja õigeusus "elada", vajalik on praktiline ja kogemuslik külg, mis muudab õigeusu (teoloogia) tervik(lik)uks, nagu seda väljendas väga lakooniliselt üks noor vaimulik.

Õigeusku on parem elada kui luterlust. [See on] terviklik (V 20-30).

Õigeusu teoloogiat nähakse täiusliku ja kõikehõlmavana, midagi ei ole sellest väljaspool.

Õigeusus on kõik olemas. See on terviklik ja kõikehõlmav. Teistes kirikutes on osad sellest tervikust [---]. Osa vaimulikust pärandist, mis Kristus 
apostlitele jättis. [---] Minu jaoks on kõige olulisem, et ta haarab kõike, kogu elu, kogu maailma, täiesti loomulikul viisil, ei lahuta [sakraalset profaansest], kõik on püha. Liturgial tuuakse ohvreid kõigi ja kõige eest, palved hõlmavad kogu maailma. Ka täielik vabadus, millega kaasneb küll ka suur vastutus, aga inimene on väga tähtis, oluline. Selline [õigeusu] maailmapilt, selle terviklikkus on nii suur, et seda tundma õppida, selleks läheb kogu elu, et seda suurust ära tajuda (V 40-50).

Õigeusu teoloogia tugineb nii kirjapandud tekstidele kui ka kirjapanemata traditsioonile. Reformatsiooni käigus kontsentreerus protestantlik kirik peamiselt kirjasõnale ja muu jäi tahaplaanile. Seda võrdlust toodi intervjuudes tihti esile, leides, et protestantlik kirik on reformatsiooni käigus "lapse koos pesuveega välja visanud", nagu väljendas vaimulik ühes eelmises tsitaadis, seevastu õigeusu kiriku teoloogiat tunnetatakse tervikliku ja kõikehõlmavana. Seda tõid välja mitmed õigeusu teoloogiat õppinud inimesed, enamasti vaimulikud ja ilmikutest teoloogid.

[---] teistel kirikutel puudub teoloogia. Nad on [---] inimese loodud sotsioloogilised ühendused. Kui kuulata nende nn teoloogiat, siis see lähtub sotsioloogilistest protsessidest, nende kirjeldamisest või ümberkirjeldamisest ja selle sidumisest evangeeliumi materjaliga. Evangeelium on õigeuskliku jaoks midagi enamat. Öigeusu teoloogia on [minu joaks] oluline. Õigeusku ei saa õppida raamatutest, doktriinide kaudu, vaid õigeusklik saab õpetuse läbi osaduse armulauas, ka sõnasalasus on sealjuures oluline, sealt kasvab välja teoloogia, see on eluga läbi põimunud. Õigeusklik elab evangeeliumi. Seda ei ole mõtet lugeda, kui see jääb lihtsalt tekstiks. Kui õigeusklik lahendab probleemi, siis lähtub ta teoloogiliselt aluselt, see on see, mis inimest tegelikult aitab. Psühholoog ja preester lähenevad probleemi lahendamisele erinevalt, milliselt aluselt keegi alustab ja milliste eesmärkideni keegi tahab jõuda, kas psühholoogiliselt rahu ja tasakaalu, kasvõi ajutist, saavutada või on eesmärk inimese tervenemine, millega kaasneb sügavam rahu (V 30-40).

Üks vaimulik kasutas võrdumit, kus ta võrdles õigeusu kirikut tööriistakastiga, kus on olemas kõik vajalikud tööriistad.

Mis on erinev teiste usulahkudega, nad on oma tööriistakastist vabatahtlikult välja visanud mitmed tööriistad ja kontsentreerunud ainult paari asja peale, sest et mingil ajalooetapil on need paar asja ära väärastatud või valesti neid kasutatud. Ja siis on tekkinud uued liikumised, uued kirikud. [---] Meil [õigeusu kirikus] on kõik see täius, mis [olemas] on (V 50-60). 
Õigeusu teoloogia mitmekesisusele ja rikkusele on kaasa aidanud esiteks tema pikk ajalugu ning teiseks lai geograafiline levik, mis on kaasa toonud rahvuslike eripärade segunemise ning teoloogiliste lähenemiste paljususe. Seda aspekti tõid välja teoloogiaga rohkem kokku puutunud inimesed.

Õigeusu teoloogiaga on see huvitav asi, et kuna õigeusu kirikud, need geopoliitiliselt moodustuvad, pole sellist ühtset keskset kantsi nagu katoliikluses, ei ole sellisel kombel tsentraliseeritud, siis on kõik geopoliitilised eripärad sees kirikus, kultuurilised ja rahvuslikud eripärad, ja see teeb selle traditsiooni tohutult rikkaks. Õigeusu kirikus ei ole kunagi igav. Ühele ja samale asjale saad vaadata kümne erinevat kanti pidi ja see kõik on õigeusklik ja see kõik on legaalne. [---] Õigeusus sees ka püütakse selgeks teha, et see koolkond on õigem või õigeusklikum kui teine, nii et ma ei tea, kui vaba see on, aga fakt on see, et ta on tohutu mitmekesine. Ikkagi erinevus rikastab. See erinevus kirikus, see on tohutu imposantne (N 37).

Selline mõtteviiside ja lähenemiste paljusus ja nende sallimine viib järgmise aspektini, mida õigeusu kirikus tuntakse nime oikonoomia all.

\section{Oikonoomia, (mõtte)vabadus}

"Ökonoomia" (oikonoomia, õigeusklikud ise kasutavad sõnastikus kirjapilti oikonomia ja seda on tõlgitud ka kui armumajapidamine, päästemajapidamine) tähistab õigeusu teoloogias vaimuliku võimet otsustada, kuidas mingit probleemi lahendada "karjatatavate kasust lähtuvalt, kannatlikkuse, vastutulelikkuse ja konkreetsete asjaoludega arvestamise seisukohast" (MP EÕK selgitav sõnaraamat ${ }^{8}$ ) ehk teisisõnu tähendab ta arukat majandamist, lunastuse tagamist reeglite targa rakendamise kaudu (Psarev 2014: 80). Õigeusus on oluline paindumatute, igas olukorras tingimusteta kehtivate reeglite puudumine. Enamik minu informantidest tunnetab seda kui vaimset vabadust ja seda toodi korduvalt välja kui õigeusu keskmes seisvat aspekti.

Õigeusus on olemas küll paksud kaanonid, aga pole kindlaid reegleid, mida tegema peab (N 33).

Minu jaoks on eriline kogu vaimsus ja kogu õhkkond, kogu osadus, mis tekib, palve meeleolu, see, et õigeusu kirik ei pressi end kunagi kellelegi peale, see, et õigeusu kirikus on väga palju vaimset vabadust (V 40-50).

[Õigeusklikke] ei kammitse dogmad, vaid nad on oma otsingutes vabad, ei takerdu piiridesse. Õigeusu dogmad ei ole nii kammitsevad, [dogmasid] võib võtta nii või võib võtta naa, on väga erinevaid lähenemisi (N 46). 
Vabadus annab arengu- ja hingamisruumi, mida on vaja usuliseks kasvamiseks.

[Õigeusu keskmes on] vabadus ja armastus, mis on kiriku sees. [---] Ma saan vabalt kasvada, omas usus, areneda. Kirik on minu jaoks see koht, vaksal, kust alustatakse teed. Kirik ei tohi inimest konserveeerida ära, kirik annab tiivad, inimene ei saa olla nagu parteilane (V 50-60).

Vabadus on õigeusu kirikus. Õigeusu kirikus ei ole isegi munkluses liine [ordusid], ei ole eristamist, kõik on ühtne, ja seal sees on niivõrd paljuöeldakse, et armasta ja tee, mis tahad. [---] Mis mind häirib [tänapäeva] Eestis, on see, et kirik on kogu aeg millegi vastu, keelame ära või kritiseerime. [---] aga püha ei saa tekitada käskude ja keeldudega, püha peab [ise tekkima], inimene peab mingi laksu saama. Arusaamad [perekonnast, elust jne] on aja jooksul muutunud. Käsu korras ei saa millestki pühalt mõelda, see ei tööta. Põhimõtteliselt õigeusk annab positiivsed alternatiivsed valikud ja inimene peab saama need valikud teha (V 50-60).

Samas rõhutavad mõned vaimulikud ka reeglitest kinnipidamise olulisusust (see seotud eetilise dimensiooniga), reeglite puudumine ei peaks nende sõnul tähendama täielikku anarhiat ja seda, et teen, mis tahan, kuid ka reeglitest kinnipidamise puhul viidatakse oikonoomiale.

Raske [on] praktiline kristlus Eesti inimese jaoks. [Näiteks] ei suudeta loobuda korratutest seksuaalsuhetest. Tuleb rakendada oikonoomiat. [---] Oluline, et inimene saaks aru, et see on terve elu muutus [liitumine õigeusu kirikuga], mitte dogmaatilised teadmised (V 30-40).

Seda rõhutavad ka teised vaimulikud, öeldes, et reeglid küll on ja neid peab täitma, aga kõike tuleb teha oma võimete piirides, Jumalale pole vaja mõttetut enesepiitsutamist.

Kiriku kaanon näeb ette, et kõik peavad paastuma. Need, kes ei paastu, võetakse armulauaosadusest maha. Sellised ettekirjutused on olemas. Kõik peavad. [---] Kes on paastunud, pattu kahetsenud, see saab aru, et see on vajalik. See aitab kaasa. Paastu rangus lepitakse preestritega kokku. Tervist ei saa rikkuda, see on täielik lollus, ennast ei pea tapma. [---] Töötab oikonoomia, kirik tuleb vastu, tuleb leida tasakaal... (V 30-40).

Sellist tasakaalustatud vabadust nimetati ka otsustusvabaduseks ja leiti, et vaba tahte osa on õigeusus suurem kui teistes konfessioonides.

Õigeusu kirikus on palju enam otsustusvabadust, see, millest Luther räägib - evangeelne vabadus, vabadus otsustada. Õigeusu kirikus on seda vabadust palju enam kui katoliku kirikus (V 40-50). 
Õigeusule omane on ka aktiivse misjoni puudumine, inimesele antakse vabadus valida, kas ta soovib sellest uksest sisse astuda või mitte, kiriku jaoks on oluline vaid ukse lahti hoidmine.

Õigeusk ei ole pealesuruv. Ema küll räägib õigeusust ja talle meeldivad need traditsioonid, aga ta ei suru seda kellelegi peale (M 22).

Seevastu üks informant, kes on liitunud kirikuga abikaasa kaudu ja tunnetab selles survestamist, leidis, et õigeusu teeb eriliseks just reeglite rohkus ning tema meelest on nendest kinnipidamine väline kombetäitmine, millel puudub tegelik sisu.

Õigeusu juures eriline - regulatsioonide hulk, takerdun neisse, unustan sisu selles hulgas. Reeglistik, regulatsioonide hulk käib tavalisele inimesele üle jõu. [Preester N] nõuab nende täitmist. Kui näed, et preester peab seda oluliseks, siis tekib tunne, et ma olen ree pealt maas ja olen veelgi enam patune. Ei ütle keegi, et vormid peaksid sisu toetama, mitte vastupidi. Paljude reeglite tähendust enam ei teatagi, see muutub mõttetuks, sest sisu ongi kaotsi läinud (N 31, vaimuliku abikaasa).

\section{Kogemuslik ja emotsionaalne dimensioon}

\section{Kogemuslikkus, intellektivälisus}

Õigeusu teoloogias on tugev apofaatiline pool, mille järgi Jumalat kirjeldatakse läbi eituste, selle kaudu, mida ta pole. Tuntud õigeusu teoloog Dionysios Aeropagita kirjutas, et "ainult eitavad väited jumaliku kohta on tõesed" (Pelikan 1977: 31). Jumalat ei saagi inimene oma sõnadega kirjeldada, selleks on vaja teisi meeli, et Jumalat mõista. Nagu eespool juba juttu oli, ei käi Jumalani jõudmine õigeusus läbi puhta intellekti.

[Mulle meeldib õigeusus see, et] eituse kaudu kirjeldada midagi, palju kasutada metafoore, kirjeldamaks kirjeldamatut, kõik see, milles luterlus ja katoliiklus ajab intellektuaalsuse sisse (V 30-40).

Sageli vastandati õigeusu vaimsust katoliikliku või protestantliku teoloogiaga, leides, et viimane on liiga ratsionaalne ja mõistuspärane ja sellise lähenemisega ei saa Jumalat seletada ega hoomata.

Minu ettekujutustes Jumalik maailm on nii salajane, et seda ei ole võimalik ratsionalistlikult lahti seletada. Minu jaoks jäi lääne kirik liiga ratsionalistlikuks. Kõiges oma suhetes, seletustes, kõik on liiga mõõdetud. Kui lugeda moraaliteoloogiat, siis see on pisidetailideni rooma õigus. 
Õigeusu kese eestikeelse õigeuskliku silmis: ühe kvalitatiivse uuringu tulemused

Rooma õigus on lääne ühiskonna üks tugevusi ja üks nõrkusi, see on meeletu nõrkus, sest see muudab inimesed niivõrd numbriliselt mõtlevateks, ratsionaalseteks. Valgustusaeg andis sellele veel hoogu kaasa (V 40-50).

Lääne teoloogia ütleb, et kõik, mida me mõistus haarab, sellega me tegeleme, aga mida me ei tea, sellega me ei tegele, sellega, milleni meie mõistus ei küündi. [---] Lääne kiriku kogemus minu jaoks oli, et sein tuleb ette, aga meie kirikus õpetus on lõputu, sa võid areneda lõpmatuseni. Saad minna sügavuti edasi. [---] Läbi piibli ja teoloogia saad maailma analüüsida, aga emotsioonide tasandil on õigeusu maailmapilt täiuslik. Seal on kõik olemas. [---] Ma ei taha olla nii ratsionaalne, ma kardan seda, et ma pean oma mõistusega kõike haarama. Emotsionaalselt on õigeusu kirik nagu isa süli, seal on turvaline olla ( $\mathrm{N} 40)$.

Kuna Jumalani ei saa jõuda puhta intellekti kaudu, tuleb seda teha teisiti, nagu seda väljendasid paljud informandid - südamega, kogemuslikult.

Kui võtta õigeusu õpetust südamega, siis saad aru nendest vastuoludest, mis Piiblis on. Võid võtta ka mõistusega, need on kaks iseasja. Vastuolud on näilised, sisemiselt on see õpetus ühtne. Õpetus tuleb tõlkida südame keelde, siis sa saad sellest aru, ja see on see, mis mulle istub ja sobib (N 46).

Sarnane vaatenurk tuli sisse, kui ma vestlesin informantidega kolmainu Jumala ja Jeesuse kaheloomuselisuse selgitustest - enamik koguduse liikmeid ja paljud vaimulikud ei hakanud tooma mingeid määratlusi või teooriaid, vaid ütlesid, et Jumalat tuleb tunnetada südamega, mitte püüda suruda tema olemust inimkeele sõnadesse, kirjeldades kirjeldamatut.

\section{Kogemuslik ja emotsionaalne dimensioon kombineerituna praktilise ja rituaalsega: palveelu, side Jumalaga}

Järgmine sagedasti välja toodud oluline aspekt on seotud palveeluga, mis on tihedalt põimunud nii praktilise ja rituaalse dimensiooniga kui ka emotsionaalsega, sisemise läbielamisega. Vahel nimetati õigeusu keskmena Jeesuspalvet.

Õigeusu keskmes - Jeesuspalve. Kui sul on väga sitt olla, siis loed seda, see hakkab ise end sinu sees lugema. Palve kaitseb sind halva eest. [---] Kindlad palved, mis võivad mingil hetkel ise end lugema hakata (N 33).

Inimesed tunnetavad ka, et üheskoos õigeusu kirikus palvetades, enamasti jumalateenistusel, saavutavad nad kontakti Jumalaga sagedamini kui üksi palvetades. Seda tõid välja nii ilmikud kui vaimulikud. 
Õigeusu kirikus saavutan liturgia kaudu sideme Jumalaga. See side ongi kõige tähtsam (N 64).

Õigeusk on kaks tuhat aastat vana! Siin ma kohtun tõesti Jumalaga, mida mul ei ole teistes kirikutes tunnet tekkinud (N 69).

Nagu eelmisest tsitaadist välja tuleb, rõhutasid paljud konvertiidid (inimesed, kel oli eelnev kogemus teiste kirikutega), et teistes kirikutes ei saavutanud nad sellist sidet Jumalaga.

Jumala arm on kogetav jumalateenistusel. Seda ma ei kogenud luteri kirikus. [Õigeusu] teenistused haarasid mind tohutult, kõik see üleelamine, see põlemine oli hoopis teistsugune, kuigi ma luteri kirikus istusin ka pingi peal ja palvetasin (V 30-40).

Luteri kirikus teenimine ja osaduse saamine, seal ei olnud sellist hingestatust, see oli selline komme, kombetalituse täitmine, ma ei tundnud seal hinge. Ei tundnud seost enda vaimse arenguga. Õigeusus kõlab see vastu, ma tunnen, et see häälestab mind õigele lainele. Enne kirikuga liitumist käisin teenistustel, alul oli väga võõras, aga see puudutas mind (M 44).

Nagu eelnevatest tsitaatidestki näha, ei saavutata sidet Jumalaga üksi kodus palvetades, pigem tajutakse seda jumalateenistusel.

Siin [õigeusu kirikus] on kord, teatud süsteem, mis töötab, minu jaoks tõesti töötab. Näiteks vabakirikus sõltub väga palju sellest, milline on jutlustaja, kui karismaatiline ta on. Õigeusu kirikus sõltub preestrist märksa vähem. Teenistuse kord on üles seatud nii, et see töötab aste astmelt, saad olla iseendaga ja oma Jumalaga ja see on su enda asi, kuidas sa seda teed või oled, keegi ei trügi sinna emotsionaalselt sisse. [See on] vahetu side Jumalaga (N 46).

See erinevus [teiste kirikutega] oli minu jaoks jumalateenistuses. Kui luteri kirikus kuulad jutlust ja see moodustab enamuse jumalateenistusest, siis õigeusu jumalateenistus rõhub pigem kontaktis olemisele Jumalaga. Et palve käiks kogu aeg ja see, kui targaks me inimlikus plaanis selle käigus saame, ei ole esmatähtis. Mulle meeldis see, et kui ma tulen kirikusse, siis ma saan lihtsalt koos palvetada inimestega, palvesse sü̈̈vida. Jutlust võin ma lugeda kodus, selle jaoks ei pea kokku tulema. Nii palju ökonoomsem paistis mulle olevat õigeusu kirik ja paistab siiani. Tegeletakse ainult kõige tähtsamaga, inimeste aega ei raisata (V 20-30). 
Jumalateenistus ei tähenda üksnes sideme saavutamist Jumalaga, vaid selles nähakse ka maapealset Jumalariiki.

Õigeusu kirikus on [jumalateenistus] algusest lõpuni vertikaalne, kõik on suunatud tulevasse jumalariiki. Luteri kirikus on seda nagu üksikud momendid, kui on euharistia, muidu kõik nagu seisab, seisad horisontaalselt maa peal. Õigeusu teenistus ei ole kuskil seal, pärast surma või teispoolsuses, aga see on siin, siin teenistusel ja see tuleb endaga kaasa võtta ka argiellu. Tagantjärele sain teada, et võibolla sama kogesid Vladimiri saadikud Konstantinoopolis ${ }^{9}$, kes ütlesid, et see oli nagu taevas maa peal. Minul oli midagi sarnast, jumalateenistus oli nagu taevariik juba siin, maa peal. See ei ole ainult teooria, vaid reaalselt, praktika (V 40-50).

Jumalateenistuse olulisim hetk on armulaud, mille kaudu inimene astub osadusse Jumala ja kogudusega. Armulaud on õigeusu kese ja seda mainisid paljud kui kõige olulisemat aspekti kirikus.

Vabadus ja sakramentide pühitsemine, see hardus, kuidas õigeusu kirikus see sakramentide pühitsemine hõlmab sind üleni, sinu fü̈usist, kõiki meeli, see on kahtlemata õigeusu kirikus tugevam kui luteri kirikus (V 40-50).

Minu jaoks on kõige tähtsam euharistia, armulaua osadus, see on kiriku kese. Kõik käib selle ümber ja see reaalne osasaamine Kristuse ihust ja verest ja selle elavaks elamine ja selle jagamine maailmaga on minu jaoks kõige tähtsam (V 40-50).

Õigeusu keskmes on Jeesus Kristus. Kasutades ühe informandi sõnu:

Õigeusu kese - kirik ümber salasuse, kirik ümber Kristuse [---]. Ilma kogunemiseta Kristuse ümber poleks kirikut. Maailmapilt on Kristusekeskne ( $\mathrm{N} 40$, vaimuliku abikaasa).

Paljud vaimulikud kinnitasid, et tee Kristuseni on nende meelest leitav vaid õigeusu kiriku kaudu.

Õigeusus Kristus on kõige keskmes. Kristus peaks olema kõige keskmes kõikide kristlike konfessioonide jaoks [aga ei ole]. See ei avaldu filosoofilises analüüsis, vaid see on kogemuslik, kui sul on kogemus Kristusest, kui sul on kogemus sakraalses elus sakramentides jne, see pole psühholoogiline, see on palju sügavam. See on Kristuse ihu. Ühe pea küljes ei saa olla mitut keha, Kristus on kiriku pea, tema on kiriku asutanud, inimene ei saa kirikut asutada. See on sisuline külg (V 30-40).

Kui ma tean, kes selle [kiriku] hierarhia tipus on, siis kõik see muu, milles ei ole hierarhiat, jääb kõrvale. Kui ma tean Kristust läbi Kristuse 
ikooni ja tunnen seda, saan kogeda, siis kõik see, mis selleni ei vii, jääb ju kõrvale. Kui luterlik kirik ja luterlik religioon, maailmakäsitlus seda mulle ei anna, kui seda mulle ei anna baptistlik religioon, siis ma elan õigeusku, ma mitte ei mõtle seda, ei tunne, vaid ma elan seda. See on hästi eksistentsiaalne, ja kui ma peaks midagi välja tooma, siis ma tookski välja selle Kristuse ikooni. Kui teised seda mulle ei paku, siis miks ma peaksin õhku vaatama, kui mul on kõrval olemas ikoon, mida ma saan kasutada, heas mõttes tarbida, ja mille kaudu sisemine maailm end avab ja elavaks elab (V 40-50).

\section{Müstika}

Arvestades, kui levinud on esoteerika tänapäeva Eestis ja kui palju räägitakse meie ühiskonnas müstikast, oli üllatav, kui vähe mainiti seda aspekti õigeusu keskmes seisva nähtusena. Müstika oli küll sageli peidetud teiste sõnade taha (mitte-mõistuspärasus, palveelu, salasused jne), aga sõnaselgelt mainiti müstikat harva.

Mulle meeldib see müstika osa, et kõik asjad pole seletatavad või tajutavad meile inimestena. Mulle meeldib, et kuskil on ruum, mida ma ei saa kontrollida, see on salapärane, mulle meeldib, et seda saab mõjutada, et see on hea, et see saab su elus asju muuta paremuse suunas, et sa saad asju mõjutada (N 48).

Kauni metafoori tõi üks informant, võrreldes kogu elu ülestõusmise müsteeriumiga:

Ülestõusmise müsteerium on kõige olulisem, see viskab taeva katuse lahti. See on kõige olulisem. Elu on nagu suur reede, mulle meeldib see metafoor (N 36).

\section{Kogemuslik ja emotsionaalne dimensioon kombineerituna eetilisega: armastus, kodusus, soojus}

Väga sageli kirjeldasid inimesed oma koha leidmist õigeusu kirikus, et nad tundsid ennast selles kirikus kui kodus ning neil polnud enam vajadust ega mõtet edasi otsida.

Ma ei saa seda öelda, et mingil hetkel ma valisin õigeusu. See tundus selline soe, kodune ja inimese nägu (V 50-60). 
Õigeusu juures kõige täpsem on see, et ma tundsin ennast koduselt siin, ma ei oska seda teistmoodi seletada, kui et ma tundsin, et see on mu kodu, mul on siin hea olla, soe olla. Samal ajal luteri kiriku kogemus - mul tekkisid iiveldushood, tasakaaluhäired, saatan sõna otseses mõttes ründas mind luteri kirikus. See ei olnud ainult minul, see oli ka pereliikmetel. See oli väga selge vaimne äratunnetamine, et see [õigeusu kirik] on minu koht. See on minu jaoks nii, see võib mõne teise jaoks teisiti olla, vastupidi jälle, et luteri kirik on kodusem. Minu jaoks oli see kodu tunne, kodune, soe tunne, hea tunne. "Hea" on jumalik väljend, seda ei saa kirjeldada, seda peab kogema. Õigeusus on selline väljend nagu magusus, see on selline magus tunne. On ütlus - meie kõige magusamale Jeesusele. [---] See on selline hea tunne, ja sinna juurde kuuluvad kõik meeküünlad, vahakü̈̈nlad, viirukisuits, rahulik laul, mõnus olek ja see soojus, nii kodune tunne, mida ma ei ole teiste konfessioonide pühakodades mitte kusagil tundnud (V 40-50).

Armastus Jumala ja ligimese vastu on see, mis peaks kirikut ühendama ja olema kiriku keskmes.

Kõige olulisem [õigeusus] on armastus, see on kõik, mis peaks meid ühendama (N 42).

Õigeusk on minu jaoks seotud lunastatud olemisega. Kes on õigeusklik või kristlane, tema on lunastanud inimene, ta on teismoodi inimene täiesti. Ta elab oma elu teistmoodi, räägib, mõtleb teistmoodi kui mittelunastatud inimene. [---] Kui inimene on lunastatud, siis on tema elu kese, õigeusu kese on armastus. Elad lihtsalt selle armastuse sees (V 40-50).

Üks informant, kes on läbi käinud palju konfessioone, leidis, et ainult õigeusus on see armastus tõeline.

Siin on tõe ja pühaduse kontsentratsioon kõrgeim, ma võin seda öelda päris kindlasti enda kogemusest. Ma olen oma elus paljudest karikatest rüübanud ja paljusid maitseid tundnud. See on mul sügavalt läbi tunnetatud, mitte mingi teoreetiline arutlus või hetke emotsioon. Kui nüüd takkajärgi võrrelda, neid kohti, kus ma käinud pole, on väga vähe [kogudusi ja uskkondi]. Mis mulle kõige suuremaks garantiiks oli, [---] et õigeusus nägin kõige kindlamalt, et inimesed nõuavad päriselt endalt ja elult armastust. Ja nad ei tagane sellest, päriselt peavad seda kõige tähtsamaks. Seda ma piidlesin, puurisin, seirasin päris pinevalt, kas see on nii. See on minu jaoks kõige olulisem [st armastus] (N 43). 


\section{Eetiline dimensioon}

\section{Alandlikkus, vagadus, teenimine}

Viimasena kirjeldatud armastus Jumala ja ligimese vastu on tihedalt seotud eetilise ja käitumusliku aspektiga, oma ego mahasalgamisega ja ligimesearmastusega. Õigeusu ühe olulise aspektina toodi välja ka sellega seonduv alandlikkus. Selle tõid rohkem välja inimesed, kes olid kokku puutunud MP EÕK või Venemaa Õigeusu Kirikuga (edaspidi VÕK), aga mitte ainult.

Mulle meeldib rohkem selline lihtsus, vagadus, alandlikkus, mida ootab õigeusu kirik ja pean seda õigeks ka. [---] Mulle meeldib enda väiksuse tunnetamine, et maailm on suur ja seda juhivad head jõud. Meeldib teenimine, enese vaimne salgamine heas mõttes, see sisaldab usaldust ( $\mathrm{N} 48$ ).

Õigeusu kirik rõhutab palju alandlikkust, luteri kirkus räägitakse sotsiaaltööst, ühed ja teised uhked üritused, aga õigeusu kirikus räägitakse rohkem alandlikkusest. See on minu elus suureks takistuseks olnud, minu ego. Selle tõttu olen elus palju vigu teinud, aga see [alandlikkus] õpetab ja kasvatab sind palju (N 64).

Mõnevõrra üllatuslikult on viimased tsitaadid pärit ametnikelt, kes töötavad vastutavatel ametikohtadel ja peavad oma igapäevatöös toimima üsna jõuliselt. Nad ei leia, et alandlikkus takistaks kuidagi nende professionaalsust ja enda kehtestamist töökollektiivis.

Alandlikkuse teema tuli sisse ka peidetumalt, oma ego võitmise ja Jumala teenimise, ligimesearmastuse seisukohalt.

Õgeusus tundus, et keskendutakse Jumala teenimisele, seal ei ole, et miski on õige või vale ja tehke nii [või naa] (V 50-60).

Jumalateenistus on koos teenimine, seda rõhutasid ka mitmed kogenumad kirikus käijad, kes on adunud, et Jumala ja teiste teenimine on olulisem kui isikliku ego teenimine.

Ma käin teenimas kirikus, enam pole mõtetki, kas ma tulen või ei, ma tulen ju teenima. Kirikus käimise aeg on möödas, nü̈̈d ma teenin kirikus. See ongi õigeusu kese. Koos teenimine, läbi iseenda Jumala teenimine, palvetame koos (N 52).

Mitmed koorilauljad tunnetavad, et nad peavad kirikus käima ja seal laulma, sest sellega teenivad nad nii Jumalat kui ka teisi inimesi, kellele on seda laulu vaja, et Jumalani jõuda. 
Kuna olen muusik, siis harmoonia, muusika väga tähtis. [---] Muusika on iseenesest harmoonia. Inimene tuleb kirikusse, et harmooniat leida, muusika aitab sellele kaasa. Mina teenin mitte otse Jumalat, vaid inimest, kellel on Jumalat vaja. Mina muusikaga aitan neil seda harmooniat leida (N 23).

\section{Jumalikustumine, piht, perekond}

Selle viimase kategooria alla panin sellised aspektid, mida mainiti harva ja mis seostuvad eetilise dimensiooniga. Mingit ühisnimetajat ma neile leida ei suutnud, sest need käsitlesid väga erinevaid nähtusi.

Patu kontseptsioon tuli kiriku keskmena väga harva jutuks. Eelpool mainisin ühte vaimuliku abikaasat, kes leidis, et preestri liigne nõudlikkus reeglitest kinnipidamisel paneb teda ennast patusena tundma. Teine informant rääkis patust, sidudes patu kontseptsiooni jumalanäolisususe ja jumalikustumisega. Katoliiklusest üle tulnud inimesena vastandas ta õigeuskliku lähenemise katoliiklikule, patu kontseptsiooni suhtes rangemale maailmavaatele.

[Jumalanäolisus] on süüme vastand. Me ikka langeme, aga inimene kui Jumala näo järgi loodud olend kannab jumalanäolisust endas kogu aeg, kogu aeg on võimalik selle poole tagasi pöörduda, selle jumalanäolisuse poole. [---] Õigeusu kirikus leitakse, et see pidev inimese sü̈̈tundele mängimine on vale [---] Õigeusu kirikus ei ole, et täitke maa ja allutage see enesele, vaid kui loodu langes, sest inimene langes ja inimene oma langusega rebis ka kõik muu loodu kaasa [---]. Me oleme üksteisega seotud ja me saame seda päästa, see on üks tervik. Ma peame pü̈̈dma seda siin elus nii palju heaks teha kui suudame. Me ei päästa ainult iseennast, vaid koos sellega ka muu loodu, see on meie võimuses. Teiselt poolt on inimesel võimalus loodu ka ära hävitada. Need on need asjad, mis on minu jaoks olulised, ma saan neist aru, need puudutavad mind, need lähevad mulle korda.

Õigeusu kirik ei tee vahet, inimese maine keha ja tema hing, on kõik võrdselt olulised, inimene on tervik, ei saa ühte ilma teiseta. Ei saa nii, et hing on puhas ja ingellik ja väga väärtuslik, aga maine keha on lihtsalt mingi kasukas, mida sa lihtsalt pead kaasa vedama, mis on roojane, vastik ja täielik ilgus, mida tuleb suretada, peksta, piinata ja põlata (N 43). 
Pihi osatähtsus EAÕK koguduste igapäevaelus on väiksem kui MP EÕK omas. Pihi olulisust mainisid küll mõned vaimulikud, kuid nad ei toonud seda välja kui eriti olulist aspekti. Seevastu üks vaimulik rõhutas, et pihi puudumine protestandi kirikus ning tungiv vajadus pihtimise järgi oli üks põhjuseid, mis tõi ta õigeusu kiriku juurde.

... tekkis tugev vajadus pihi järele. Protestandi traditsioon välistab selle (V 30-40).

Veel üks informant tõi välja õigeusu perekonnaõpetuse kui aspekti, mis teda selle kiriku juures esimese asjana köitis ja millest sai alguse ka sügavam armastus õigeusu vastu.

Katoliku kirik on saanud tugevat mõjutust protestandi kirkust, tahes-tahtmata. Esimese asjana, mis mind vapustas sügavalt, kui mulle selgitati, millel lääne kirikus perekonnaõpetus põhineb. See põhineb prokreatsioonil ehk "saagu teid palju, võtke maa, alistage see enesele, tehke sugu!" Need on põhialused. Õigeusu kirikus on abielu kahe inimese ühine vaimne kasvamine. Laps ei ole ei eesmärk, ei kohustus (N 43).

\section{Sotsiaalne ja institutsionaalne dimensioon: munklus}

Selle aspekti tõi välja vaid üks informant, ainus minu uurimuses osalenud nunn. Ta toob küll oma vastuses välja ka teoloogilise poole, kõrbeisade kirjutised jm, samuti kiriku ajaloolise algupärasuse, kuid määravaks sai tema puhul usu valikul siiski munklus, selle sisu ja sisemine korraldatus.

Õigeusu juurde jõudsin munkluse kaudu. [---] Õigeusu juurde jõudmine tundus mulle asja tuumani jõudmine olevat, ja munklus veel eriti. [---] Munklus pani õigeusku üle tulema. Katoliikluse munklus on poole tee peal seisma jäämine. Minu jaoks on õigeusk see kõige algsem, algupärasem. Ka järjepidevus on oluline, mungasüsteemi pole jaotatud ordudesse, kus igaühel on oma spiritualiteet, vahel vaatad, et kristlusest räägitakse vähem kui ordu asutajast. [---] Ratsionaalne ta ei ole, ma ei ole jõudnud õigeusu juurde teoloogiliste õpingutega. Ma elasin kaheksa aastat Roomas, kui ma lugesin kirikuisasid, vanakeste õpetusi, siis mulle tundus see nii ausana. Katoliku kloostris elades oli teine mentaliteet, see oli midagi, mis hakkas mind lõpuks häirima, see polnud päris ausalt enese ja teiste inimeste sisse vaatamine. See ausus mind nii liigutas, see tegi mind nii januliseks, see oli aastate pikkune tee iseenese sees, see polnud teadlik. Ühel päeval olin ma sealmaal, et ma vahetasin kloostrit (N 52). 


\section{Diskussioon}

Kui teha eespool toodud vastustest kokkuvõte, võib öelda, et õigeusu keskmena ehk kõige olulisemate aspektidena õigeusus nähti religiooni kõiki dimensioone, kuigi mitte võrdsel määral. Kuna minu uurimus on kvalitatiivne, ei saa ma teha mingeid arvulisi järeldusi, kuid ma saan oma valimi põhjal välja tuua üldised suundumused ja eripärad eestikeelsete õigeusklike seas. Ma ei leidnud kirjandusest ühtki sarnase küsimusepüstitusega varasemat uurimust, seega ei saa ma kuigi palju tugineda kirjanduse andmetele ja neid oma andmetega võrrelda.

Mingit ühisnimetajat õigeusu keskme kohta minu andmete põhjal välja tuua ei saa. Ma ei leidnud aspekti, mida näeksid eesti keelt kõnelevad õigeusklikud tüüpiliselt oma usu keskmes seisvana.

Kõige sagedamini toodi välja õigeusu kogemuslikkust ja südame suurt osakaalu usus. Väga sageli kohtasin vaatenurka, et Jumalat ei saa mõista ja temaga sidet saavutada intellektuaalselt, dogmaatiliselt, mingite teooriate kaudu, vaid ainult südame ja tunnetuse kaudu. See on kooskõlas seisukohaga, mille järgi peaks iga elava teoloogia alus olema vaimulik kogemus ning mille järgi ei saa terviklikku teoloogiat õppida ega selgitada, vaid ainult elada (nt Sheldrake 1998: 3). See seisukoht on omane ka õigeusule, ja seda võiks kokku võtta eelmise aastatuhande vahetuse õigeusu teoloogi Siimeon Uusteoloogi sõnadega: "Õigeusu kristoloogiat ei pea ainult intellektuaalselt uskuma ja tunnistama, vaid seda peab ka kogema" (Pelikan 1974: 259).

Informandid, eriti teistest konfessioonidest üle tulnud, vastandasid sageli õigeusu teoloogia katoliikluse ja luterluse liigsele intellektuaalsusele ning leidsid kaunis üksmeelselt, et emotsionaalsus ja kogemuslikkus on see, mis teeb õigeusu nende silmis terviklikuks, arusaadavaks ja südamelähedaseks ning et vaid sel viisil suudavad nad saavutada sidet Jumalaga.

Teine oluline aspekt, mida leiti õigeusus olevat rohkem kui teistes konfessioonides, oli oikonoomia, mida esitati erinevates sõnastustes, peamiselt kui mõtte- või tegutsemisvabadust. Oikonoomia rakendamist erinevate olukordade lahendamisel on võrreldud arstimi doseerimisega (McGuckin 2014: 80), reegleid rakendatakse teatud juhtudel suurema "doosiga", teisel juhul väiksema, vastavalt haiguse iseloomule ja arstitava seisundile. Tänapäeva Eesti religioossele valdkonnale on iseloomulik individualiseerumine ja sünkretism (nt Altnurme 2005: 193, 195-200; Pärkson 2007: 196), mille puhul inimene nopib religioonist välja talle sobivad komponendid ja jätab tähelepanuta teised, ebameeldivamad. Võib spekuleerida, et sellise lähenemise puhul nähakse oikonoomias mugavat õigustust, kuigi see pole oikonoomia tegelik sisu, vaid äärmine lihtsustus. 
Veel üks sagedamini välja toodud aspekt oli seotud institutsionaalse kiriku ja palveeluga. Väidetavasti leiavad õigeusklikud, et ühine jumalateenistusel käimine on nende usuelu oluline osa (Stamoolis 1986: 11). Seda väidet kinnitasid paljud minu valimi õigeusklikud ja see oli üllatav, sest nagu eespool juba öeldud, siis on Eestis üldine suundumus pigem religiooni individualiseerumine (sel teemal vt Lea Altnurme mitmeid kirjutisi, nt 2005, 2012 jt) ning institutsionaalse usklikkuse vähenemine (vt Eesti Kirikute Nõukogu tehtud uuringute tulemusi http://www.ekn.ee/astu_alla.php). Nende uuringute alusel välja antud kogumikus kirjutavad Raigo Liiman ja Tarmo Tuisk: "Usk on tänapäeval liikunud privaatsfääri. Kirik [---] ei ole enamusele enam kollektiivne kogemus..." (Liiman \& Tuisk 2012: 116). Sarnast suundumust sedastab samas kogumikus ka Lea Altnurme (Altnurme 2012: 195). Seetõttu on huvitav, et nii paljud informandid tõid välja just institutsionaliseeritud usu osatähtsuse, leides, et sideme Jumalaga saavutavad nad mitte üksi kodus palvetades, vaid esmajärjekorras üheskoos jumalateenistusel koos palvetades, armulaual käies, toetades seega eespool toodud väidet jumalateenistusel käimise olulisuse kohta. Paljud konvertiidid rõhutasid koguni, et eelmises konfessioonis nad sellist sidet saavutada ei suutnud, ning side Jumalaga on nendel võimalik ainult õigeusu kirikus.

Üks põhjus, miks minu tulemused erinevad teistest Eestis saadud tulemustest, on see, et EKNi tellimusel OÜ Saar Poll läbi viidud küsitluses "Elust, usust, usuelust 2010" ei tehtud vahet konfessionaalsel kuuluvusel ning uuringusse kuulus ka neid, kes end usklikeks ei pidanud. Võib arvata, et õigeusklikud hindavad institutsionaliseeritud usu praktiseerimist rohkem kui keskmine eestlane. See on seotud muuhulgas ka asjaoluga, et õigeusu kirikus on sügavalt juurdunud traditsioon jumalateenistusel koos palvetada. Tsiteerides ühte misjoni käsiraamatut, “õigeuskliku jaoks kogu teoloogia on jumalateenistus, ja kogu jumalateenistus on teoloogia" ning "teoloogia väljendub rohkem liturgias ja palvetes kui dogmaatikas" (Stamoolis 1986: 10).

Traditsioonide muutumatus, sealhulgas jumalateenistuse korra muutumatus, oli üks sageli välja toodud aspekte, mida rõhutati kahest seisukohast ühest küljest sisendab muutumatus ja traditsioonide järjepidevus usaldusväärsust, autentsuse tunnet, ning teiseks on see lihtsalt emotsionaalselt mõnus ja tekitab inimeses koduse ja turvalise tunde. Emotsionaalset mõnusalt ja koduselt tundmist tõid välja nii minu kõige nooremad kui ka kõige vanemad informandid, nii vaimulikud kui ka ilmikud, kes tunnistasid õigeusu kirikus olles päralejõudmise ja rahu tunnet. Ka jumalateenistuse korra ja tekstide muutumatus tekitab sarnase tunde ning aitab inimesel paremini palvesse süüvida, sest tema tähelepanu ei tõmmata eemale ootamatute või harjumatute 
elementidega. Selles osas ei erine minu valimi õigeusklikud varem tehtud rahvusvahelistest uuringutest (vt nt Furseth \& Repstad 2007: 128), mille kohaselt on oluline rituaalide muutumatus, mis tekitab sideme uskliku ja traditsiooni vahele. Ei erine need tulemused ka Eestis tehtud uuringutest, mille järgi 70\% Eesti Kirikute Nõukogu tellimusel Saar Polli korraldatud küsitlusele "Elust, usust, usuelust 2010" vastanutest leidis, et kirik peaks jääma oma traditsioonide juurde ning püüdma neid võimalikult vähe kaasajastada (Soom 2012: 259).

Teisi religiooni aspekte toodi välja vähem. See, et väline külg ja esteetiline nauding mõjutab inimese religioosseid valikuid, on õpikutõde (vt nt religioonisotsioloogia õpik Furseth \& Repstad 2007: 123; ka nt James 2011: 485 jj jm). Tuntud katoliku teoloog Hans Urs von Bathasar ütles koguni, et kristlus on esteetiline religioon par excellence (Balthasar 1982: 216; vt ka Hart 2003: 16). See teema paelub paljusid uurijaid ja esteetilise külje rollist õigeusus on korraldatud isegi konverentse (nt 2004 Haagis).

Kokkuvõtvalt võib öelda, et esteetilist külge peetakse õigeusus oluliseks religoossust mõjutavaks teguriks isegi sekulaarsetes ühiskondades. Religiooniuuringutes peetakse ilu religioossete tunnete seletajaks. Nähtav külg on sageli peamiseks religiooniga suhtestumise viisiks, kuidas saadakse esimene kontakt religiooniga (Van der Bercken \& Sutton 2005: ix). Seega oli kõigiti ootuspärane, et väline külg oli oluline ka paljude intervjueeritute meelest. Tavaliselt polnud see keskse tähtsusega, aga piisavalt oluline, et seda mainida. Kui ma palusin selgitada, mis eristab õigeusu kirikut teistest konfessioonidest, tõid need, kes ei osanud või ei tahtnud süüvida teoloogilistesse arutlustesse, välja just välise erinevuse.

Ainelise dimensiooni juures mainiti sageli ikoone kui õigeusu eripära. Ikoone peetaksegi õigeusu väljendajateks (Ouspensky 1978: 10). Ikoon ei ole muidugi lihtsalt pilt ja nende ilu ei saa käsitleda eraldiseisvana, need on seotud teoloogia ja lunastus(loo)ga, nagu seda väljendas kuulus neljanda sajandi õigeusu teoloog Gregor Nyssast: "Ilu on lunastuse sümbol" (Scott 2006: 76). Kohtasin nii informante, kellele ikoon tähendas lihtsalt välist ilmingut (peamiselt vanema generatsiooni esindajad, aga ka paljud traditsioonilistest õigeusu peredest pärit informandid), kui ka neid, kel olid teadmised ikooniteoloogiast ja kes oskasid käegakatsutavast ja silmaga nähtavast kaugemale näha, seostada seda intellektuaalse dimensiooniga.

Intellektuaalse dimensiooni üks osa on narratiivid ning seda dimensiooni tõid oma usu keskmes seisvana välja mitmed vaimulikud ja teoloogilist haridust saanud inimesed, kellele on oluline kiriku järjepidevus ja algupärasus. Lisaks oli mitmele informandile oluline õigeusu rahumeelse misjoni vorm, mida vastandati mõõga ja verega toodud katoliiklusele või sakslaste poolt peale suru- 
tud luterlusele. Seda vaatenurka kohtasin sagedasti Setumaal, Eesti vanimas õigeusu piirkonnas, kus õigeusk on lahutamatult seotud setude identiteedi ja rahvausuga (Jääts 1998; Kattai 2006). Millal õigeusk Setumaale jõudis, ei ole täpselt teada, aga kuna setude naabruses oleva Irboska õigeusu kiriku kohta leidub kirjalikke teateid juba 1340. aastast ning arvatakse, et kirik võis seal olla isegi varem, 11. või 12. sajandil (Plaat 2011; Piho 2011), võib eeldada, et õigeusk jõudis Setumaale umbes samal ajal ning on igati mõistetav, miks see aspekt setude meelest nii oluline on. Mõnele informandile oli oluline ka narratiiv, et õigeusk on meile jõudnud Bütsantsist ja pole "vene usk". Nende puhul on oluline ajalooliste faktide mütologiseerimine, et anda religioonile õige ideoloogiline kontekst ehk arvamus, et õigeusk ei seostu venestamise ja venelastega.

Mitmed vaimulikud ja teoloogiat õppinud inimesed tõid õigeusu keskmena välja õigeusu teoloogia terviklikkuse ja kõikehõlmavuse, nagu ka eespool mainitud. See terviklikkus koosneb nii intellektuaalsest kui ka kogemuslikust poolest, emma-kummata pole tervikut. On arvatud, et liigne keskendumine doktriinidele ja õpetusele peletab inimesed kirikust eemale, kogemusi otsima, kuid ka ainult emotsioonid ilma traditsioonita viivad subjektiivsesse spirituaalsesse nartsissismi ja Jumal kaotatakse hoopis silmist (McGrath 2003: 12). Õigeusu teoloogia on otseselt seotud inimese eluga, ei tehta vahet "jumaliku müsteeriumi personaalsel kogemisel ja kiriku kinnitatud dogmadel" (Stamoolis 1986: 10). Seda terviklikkust mainisid ka tavalised ilmikud, kes polnud katehheesis käinud ega osanud seda seisukohta väljendada muul viisil, kui et õigeusus on kõik olemas ja rohkemat polegi vaja.

Emotsionaalse ja kogemusliku dimensiooni alla kuulub ka müstiline komponent. Vladimir Lossky arvates on kogu õigeusu teoloogia teatud mõttes müstiline (Lossky 1997: 7) ning müstika pole õigeusu teoloogiaga mingilgi määral vastuolus. Eelnevalt olen sama uuringu käigus kogutud andmete põhjal leidnud, et valdav enamus õigeusklikest on kogenud oma elus midagi müstilist (Eek 2015 ilmumas), kuid müstikat õigeusu keskmes oleva nähtusena üldjuhul sõnaselgelt välja ei toodud. Müstika või müstiline kogemus tuli küll sageli jutuks, aga võimalik, et see ongi õigeuskliku igapäevaelu osa, et seda ei osata enam eraldiseisva aspektina määratleda.

Viimaseks toon välja aspektid, mida nimetati vaid korra. Nendeks olid eetilise dimensiooni poolelt jumalanäolisus, perekonnaõpetus ja piht ning institutsionaalse dimensiooni poolelt munklus. Viimase tõi mõistetavalt välja inimene, kes on seda pikaajaliselt praktiseerinud, see ongi tema elu. Munklust mainisid ka paljud vaimulikud, kuid see ei olnud nende silmis õigeusu kõige olulisem aspekt, vaid pigem üks paljudest õigeusu eripäradest. Eelpool mainitud eetilised aspektid toodi alati välja võrdluses mõne muu konfessiooniga ning vähemalt 
kahel juhul oli see aspekt nihkunud tähelepanu keskmesse seetõttu, et informandil oli olnud sellel teemal konflikt oma eelmises konfessioonis. Seetõttu oli see teema omandanud tema silmis keskse tähtsuse ja seda rõhutati kui õigeusu eripära.

Arvamus õigeusust, sellest, mis seal oluline on, on tihedalt seotud inimese religioosse identiteediga. On väidetud, et mõned inimesed saavad oma identiteeti luua ja teised mitte (Clarke 2008: 528). Tõenäoliselt on aktiivne osalus identiteedi loomise protsessis väiksem nendel, kes on kasvanud õigeusus, õigeusk on nende identiteedi osa, aga nad ei ole ise teadlikult osalenud selle kujundamises. Teised loovad selle oma kogemuste, tõekspidamiste, ümbritsevate mõjutuste baasil. Identiteedi loomise protsessis on teatud seaduspärad, millest minu tulemuste valguses kerkis kõige ilmekamalt esile identiteedi konstrueerimine vastandumise alusel. ${ }^{10}$ Kokkuvõtvalt võib öelda, et identiteet luuakse teiste alusel, antud juhul teiste konfessioonide alusel, selle põhjal, mis neil puudu leitakse olevat (Derrida 1981). Identiteedi loomine hõlmab sel juhul millegi välja jätmist (Hall 1996: 17). Kultuuriline identiteet, milleks võib pidada ka religioosset identiteeti, luuakse erinevuse alusel ja selle käigus luuakse endale mingi pilt sellest, millised on need teised, kellele vastandudes oma identiteet luuakse (Clarke 2008: 523). Vastandumise kaudu õigeusu identiteedi konstrueerimise protsessil on mitmeid vorme (vt nt Makrides 2014: $141 \mathrm{jj}$, samuti sealsed viited selle nähtuse kohta, kus on kirjeldatud lääne(likule) kirikule vastanduvat õigeusu identiteedi loomist ${ }^{11}$.

Õigeusklikest peredest pärit inimesed, kes ei olnud aktiivselt osalenud oma identiteedi loomises, olid minu valimis vähemuses. Need, kes olid õigeusklikus ümbruskonnas kasvanud, ei osanud või ei soovinud võrrelda õigeusku teiste konfessioonidega, ning nende arvamus õigeusust oli kujunenud enamasti perekonnatraditsiooni alusel. Märkimist väärib siinkohal ka venelaste identiteedi seos õigeusuga. Seda seost on korduvalt näidatud ka Eesti vene keelt kõnelevate inimeste juures (nt Liiman 2001; Pärt 2012; Cleary 2014) ja seda nähtust võisin sedastada ka oma valimis, eriti nende puhul, kellele eesti keel polnud emakeel. Eesti keelt kõnelevad inimesed üldjuhul ei seo oma õigeusklikkust rahvuslusega. Erandlikud on setud, kelle identiteet on tihedalt seotud õigeusuga (vt viited eespool).

Ülejäänud informandid, keda oli valdav enamus, konstrueerisid oma usulise identiteedi ja arvamuse õigeusu olulistest aspektidest, vastandudes mõnele teisele konfessioonile: õigeusus on teisiti kui budismis, luterluses, baptismis. Identiteedi loomine käib sel juhul millelegi vastandumise kaudu (Hall 1996: 17), ja nagu oli näha eelpool toodud tsitaatidest, võis seda kõnealuses uurimuses sageli kohata. Huvitaval kombel on setude kohta väidetud, et nende identiteet 
on konstrueeritud muu hulgas just väljastpoolt tulnud elementide oma kultuuri ja identiteeti importimise kaudu: "kultuuri haaratakse elemente välistest, mis põimitakse koos üheks tervikuks ja seeläbi omandab [kultuur] eripärased jooned" (Kattai 2006: 241), kuigi ilmselgelt on nende identiteediloomise protsess keerukam kui vaid see üks aspekt.

Vastandumise kaudu identiteedi loomisel arvatakse tihti teiste kohta seda, mida nood ise enda kohta ei tunnistaks. Seda kohtas minu intervjuudes sageli, kui baptistidele ja metodistidele heideti ette ülearust lobisemist, luterlusele liigset külmust ning katoliiklastele "Rooma õigust" ja liigset ratsionaalsust. Vaevalt asjaosalised ise endid sellisena näevad, kuid see kuvand aitas õigeusklikel end sellele vastandades leida enda usus parimat - teoloogia sügavus, jumalateenistuste kindel kord, jutluste napisõnalisus ning samas tunnetuslikkus ja kogemuslikkus, mis tagab ka Püha Vaimu kogemise. Seda kõike ei peetud mujal võimalikuks. Selline vastandudes identiteedi loomine viib hõlpsasti sallimatusele endast erinevate suhtes (Clarke 2008: 511). Otseselt sallimatust ma oma intervjuudes ei kohanud, küll aga tajusin teatavat üleolekut või isegi mitteõigeusklike haletsemist. Näiteks öeldi korduvalt, et "protestandid viskasid ju lapse pesuveega välja”, või isegi "[öeldakse], et õigeusklikud istuvad altari juures, aga protestandid istuvad koridoris, kaugemale pole nad jõudnud" (N 33). Samas oli ka palju neid, kes küll möönsid kirikute erinevust, aga arvasid, et see erinevus pole oluline ja lunastatud võib saada ka väljapool õigeusu kirikut. Mitmed vaimulikud hoidusid arvatavasti teadlikult õigeusku teiste konfessioonidega võrdlemast.

Kõige olulisemad aspektid teistes konfessioonides, millele vastanduti, oli külmus, ratsionaalsus, liigne intellektikesksus, aga ka tühisus ja pinnapealsus, mille vastandomadusi nähti õigeusu keskmes olevat. Veel üks aspekt, millele vastandades loodi oma usulist identiteeti, on tule ja mõõga müüt. Sellele müüdile vastandumise olulisust identiteedi loomisel on sedastatud ka varem (vt nt Karo 2007: 16 jj).

\section{Kokkuvõte}

Püüdsin oma uuringus leida vastust küsimusele, mida peavad eestikeelsed õigeusklikud oma religiooni keskmeks, kõige olulisemaks aspektiks õigeusus. Mingit ühte ja ainsat tüüpilist aspekti ma tuvastada ei suutnud. Informandid mainisid õigeusu keskmes olevatena religiooni kõiki seitset dimensiooni - praktilist ja rituaalset, kogemuslikku ja emotsionaalset, narratiivset või müütilist, 
doktriini ja filosoofilist, eetilist ja õiguslikku, sotsiaalset ja institutsionaalset ning materiaalset dimensiooni.

Kõige sagedamini esile toodud aspektid olid seotud kogemusliku ja emotsionaalse ning rituaalse dimensiooniga. Rõhutati õigeusu kogemuslikkust, traditsioonide muutumatust, palveelu ehedust võrreldes teiste konfessioonidega, mis kõik kokku tekitab õigeusklikes koduse ja mõnusa tunde. Õigeusku nähakse tervikliku ja kõikehõlmavana, mõtte- ja tegutsemisvabadust võimaldavana. Õigeusule omast kindlate kõikidele samade normide järgi kehtivate reeglite puudumist (oikonoomiat) kiputakse kasutama vabandusena, et jätta tähelepanuta reeglid, mis tunduvad ebameeldivad. Ka ainelise dimensiooniga seotud nähtusi mainiti usukeskmest rääkides üsna sageli. Filosoofiline dimensioon oli tähtsam vaimulike ja teoloogiat õppinute silmis. Narratiivsel dimensioonil, eriti jutustusel õigeusu saabumise kohta, oli keskne koht Setumaa õigeusklike meelest. Eetilise dimensiooniga seonduvalt mainiti teistest aspektidest sagedamini kristlikku armastust. Institutsionaalse dimensiooni nägemine õigeusu keskmena oli pigem erandlik.

Uurimusest ilmnes, et inimese religioossel identiteedil on tihe seos sellega, mida ta õigeusklikuna õigeusust arvab. Intervjuude põhjal etendas religioosse identiteedi kujunemisel kõige olulisemat rolli vastandumine teiste konfessioonidega.

\section{Kommentaarid}

1 Uurimistööd on toetanud Eesti Vabariigi Haridus- ja Teadusministeerium (sihtfinantseeritav teadusteema SF0180026s11) ja Euroopa Liit Euroopa Regionaalarengu Fondi kaudu (Kultuuriteooria Tippkeskus).

${ }^{2}$ Küsimused õigeusu keskme leidmise kohta oli järgmised: "Mida tähendab teie jaoks õigeusk, mis on õigeusus kõige olulisem, mis on teie meelest õigeusu kese? Kuidas mõistate õigeusku võrreldes näiteks luterlusega, mis on teie silmis see vahe, mis eristab õigeusku teistest konfessioonidest?” Ma ei püüdnud luua usklikkuse gradienti, valimi moodustavad inimesed, kes ise ennast õigeusklikuks peavad, sõltumata nende kirikus käimise sagedusest või usuliste teadmiste sügavusest.

3 Kaalusin ka Starki ja Glocki usklikkuse dimensioonide kasutamist (ideoloogiline, intellektuaalne, rituaalne, kogemuslik, tagajärgne dimensioon; Stark \& Glock 1969), kuid Smarti süsteem tundus õigeusu keskme uurimiseks kohasem, kuivõrd ma uurisin seda, mis on inimese silmis usu keskmes, mitte seda, kuidas ja kas inimesed usuvad.

4 Apofaatiline mõtteviis põhineb sellel, et Jumalat kirjeldatakse välistavalt, selle kaudu, mida ta ei ole. Jumal on niivõrd kõrgemal inimlikust kirjeldus- ja mõistmisvõimest, et ükski jaatav väide Jumala kohta ei saa olla täielikult tõene.

5 Vt lähemalt lk 58. 
${ }^{6}$ Kasutan kirjapilti setu ja Setumaa, kuigi asjaosalised kasutavad ise sageli kirjapilti seto ja Setomaa, väites, et sõnal setu on halvustav kõla. Kuna mina seda halvustavat varjundit kuidagi ei tunneta, jään siinkohal traditsioonilise kirjapildi juurde.

7 Mõeldud on kirikuid, kes lahkusid õigeusu kiriku perekonnast enne 4. Halkedoni oikumeenilist kirikukogu, nn mitte-Halkedoni kirikud, siin silmas peetud miafüsiite (vananenud nimetusega monofüsiite).

8 http://www.orthodox.ee/orthodic/09_i/ikonomia.html (28. mai 2014).

9 Mõeldud on Kiievi suurvürsti Vladimir Suurt, kes aastal 988 lasi Venemaa õigeusku ristida ja kes enne seda saatis oma saadikud Konstantinoopolisse õigeusu kohta andmeid koguma.

${ }^{10}$ Muidugi oli ka neid, kes lõid oma identiteedi just vastupidiselt - samastumise alusel, soovist kellegagi sarnaneda, kuid see ei tulnud vastustes nii ilmekalt esile kui vastandumine.

${ }^{11}$ Vastupidist nähtust, õigeusklike alavääristamist võrreldes luterlusega, kohtame Jakob Hurda ja hiljem Karp Ustavi juures, kes kirjutasid setu õigeusklike kohta, et nende usuelu on väline ja primitiivne, vastandades seda kuvandit "kaasaegsetele" luterlastele (Hurt 1904; Ustav 1908).

\section{Kirjandus}

Altnurme, Lea 2005. Kristlusest oma usuni. Uurimus muutustest eestlaste religioossuses 20. sajandi II poolel. Tartu: Tartu Ülikooli kirjastus.

Altnurme, Lea 2012. Mida võiks kirik teada eestimaalaste individuaalsest religioossusest. Jõks, Eerik (toim). Astu alla rahva hulka. Artikleid ja arutlusi Eesti elanikkonna vaimulaadist. Tallinn: Eesti Kirikute Nõukogu, lk 193-212.

Balthasar, Hans Urs van 1982. The Glory of the Lord: A Theological Aesthetics 1. San Fransisco: Ignatius.

Bercken, William Petter van den \& Sutton, Jonathan 2005. Aesthetics as a Religious Factor in Eastern and Western Christianity. Selected Papers of the International Conference Held at the University of Utrecht, the Netherlands, in June 2004. Leuven \& Paris \& Dudley, MA: Peeters.

Bernard, Harvey Russell 2000. Social Research Methods. Qualitative and Quantitative Approaches. Thousand Oaks, Calif: Sage Publications.

Bertaux, Daniel 1981. From the life-history approach to the transformation of sociological practice. Bertaux, Daniel (toim). Biography and society: The life history approach in the social sciences. London: Sage Publications, lk 29-45.

Clarke, Simon 2008. Culture and Identity. Bennett, Tony \& Frow, John (toim). The SAGE Handbook of Cultural Analysis. London: SAGE Publications, lk 510 - 529 (http:// dx.doi.org/10.4135/9781848608443.n25). 
Cleary, Elizabeth Ann 2014. The Impact of Religion on Minority Identity and Community: A Case Study of Russian Orthodoxy and the Russian Minority in Estonia. Tartu: Tartu Ülikooli Euroopa Kolledž, magistritöö (http://dspace.utlib.ee/dspace/bitstream/ handle/10062/45120/Cleary_Elizabeth_2014_MA.pdf?sequence=1 - 8. juuli 2015).

Derrida, Jacques 1981. Positions. Chicago: Chicago University Press.

Eek, Liina [2015]. Eestikeelse elanikkonna õigeusklikuks olemise põhjustest. Eek, Liina (toim). Mitut usku Eesti. IV. Valik usundiloolisi uurimusi. Õgeusu eri. Tartu: Tartu Ülikooli kirjastus [ilmumas].

Furseth, Inger \& Repstad, Pål. 2007. An Introduction to the Sociology of Religion. Classical and Contemporary Perspectives. Aldershot: Ashgate.

Geertz, Clifford 1993. Religion as a Cultural System. The Interpretation of Cultures. Selected Essays. London: Fontana Press (https://isites.harvard.edu/fs/docs/icb.topic152604. files/Week_4/Geertz_Religon_as_a_Cultural_System_.pdf - 8. juuli 2015).

Guest, Greg \& Bunce, Arwen \& Johnson, Laura 2006. How many interviews are enough? An experiment with data saturation and variability. Field Methods 18, lk 59-83.

Hall, Stuart 1996. Who Needs Identity: Questions of Cultural Identity. Hall, Stuart $\&$ du Gay, Paul (toim). Questions of Cultural Identity. London, Thousand Oaks, New Delhi: Sage Publications, lk 1-17.

Hart, David Bentley 2003. The Beauty of the Infinite, The Aesthetics of Christian Truth. Michigan, Cambridge, UK: William Eerdmans Publishing Company, Grand Rapids.

Hurt, Jakob 1904. Über die Pleskauer Esten oder die sogennanter Setukesen. Anzeiger der Finnish-Ugrishen Forchungen. Band III. Helsinki: Helsinfors, lk 185-205.

James, William 2011 [1902]. The Varieties of Religious Experience. Cambridge University Press (http://dx.doi.org/10.1017/CBO9781139149822).

Jääts, Indrek 1998. Setude etniline identiteet. Studia Ethnologica Tartuensia 1. Tartu: Tartu Ülikool.

Karo, Kaja 2007. Rahvuslikud narratiivid ja religioon. Altnurme, Lea (toim). Mitut usku Eesti. II. Valik usundiloolisi uurimusi: kristluse eri. Tartu: Tartu Ülikooli kirjastus, lk $13-46$.

Kattai, Ulla 2006. Setode identiteedikontseptsioonidest oma-võõra vastanduses. Hortus Semioticus 1, lk 233-243 (http://www.ut.ee/hortussemioticus/1_2006/kattai.htm - 8.juuli 2015).

Liiman, Raigo 2001. Usklikkus muutuvas Eesti ühiskonnas. Tartu: Tartu Ülikooli kirjastus.

Liiman, Raigo \& Tuisk, Tarmo 2012. Eestimaalaste arusaamad usu- ja moraaliküsimustes 1990-2010. Jõks, Eerik (toim). Astu alla rahva hulka. Artikleid ja arutlusi Eesti elanikkonna vaimulaadist. Tallinn: Eesti Kirikute Nõukogu, lk 113-142.

Lossky, Vladimir 1997. Mystical Theology of the Eastern Church. Crestwood: St Vladimir's Seminary Press. 
Makrides, Vasilios N. 2014. 'The Barbarian West' - A Form of Orthodox Christian Anti-Western Critique. Krawchuk, Andrii \& Bremer, Thomas (toim). Eastern Orthodox Encounters of Identity and Otherness. New York: Palgrave MacMillan, lk 141-158.

McGrath, Alister 2003. Loving God with Heart and Mind: The Theological Foundations and Spirituality. George, Timothy \& McGrath, Alister (toim). For all the Saints. Evangelical Theology and Christian Spirituality. London: Louisville, John Knox Press, lk 11-26.

McGuckin, John Anthony (toim) 2014. The Concise Encyclopedia of Orthodox Christianity. Chichester (UK): Wiley-Blackwell.

Morse, Janice 1994. Designing funded qualitative research. Denzin, Norman \& Lincoln, Yvonna (toim). Handbook for qualitative research. Thousand Oaks, CA: Sage, lk 220-235.

Ouspensky, Leonid 1978. Theology of the Icon. Crestwood, New York: St Vladimir's Seminary Press.

Pelikan, Jaroslav 1974. The Spirit of Eastern Christendom. The Christian Tradition. A History of the Development of Doctrine 2. Chicago \& London: The University of Chicago Press.

Pelikan, Jaroslav 1977. The Spirit of Eastern Christendom. The Christian Tradition. A History of the Development of Doctrine 2. Chicago \& London: The University of Chicago Press.

Piho, Mare 2011. Setode usk ja Setomaa tsässonad. Raudoja, Ahto \& Mäkeläinen, Tapio (koost). Setomaa tsässonad. Obinitsa: SA Setu Kultuuri Fond, lk 13-60.

Plaat, Jaanus 2011. Orthodoxy and Orthodox Sacral Buildings in Estonia from the 11th to the 19th Centuries. Folklore: Electronic Journal of Folklore 47, lk 7-42 (http://dx.doi. org/10.7592/FEJF2011.47.plaat).

Psarev, Andrei 2014. Canon Law. McGuckin, John Anthony (toim). The Concise Encyclopedia of Orthodox Christianity. Chichester (UK): Wiley-Blackwell, lk 79-86.

Pärkson, Katti 2007. Muutustest tänapäeva kristlikus vaimsuses. Altnurme, Lea (toim). Mitut usku Eesti. II. Valik usundiloolisi uurimusi: kristluse eri. Tartu: Tartu Ülikooli Kirjastus, lk 150-200.

Pärt, Irina 2012. Jumalaotsingud “jumalata" maal: usku pöördumine, traditsioon ja põlvkonnad vene õigeusuliste seas. Aarelaid-Tart, Aili (koost). Nullindate kultuur II. Põlvkondlikud pihtimused. Tartu: Tartu Ülikooli kirjastus, lk 150-181.

Scott, Mark S. M. 2006. Shades of Grace: Origen and Gregory of Nyssa's soteriological Exegesis of the Black and Beautiful Bride in Song of Songs. Harvard Theological Review 99 (1), lk 65-83 (http://dx.doi.org/10.1017/S001781600600112X).

Sheldrake, Philip 1998. Spirituality and Theology: Christian living and the Doctrin of God. Marynkoll \& NewYork: Orbis Books.

Smart, Ninian 1996. Dimensions of the Sacred: An Anatomy of the World's Beliefs. Berkeley \& Los Angeles, CA: University of California Press.

Smart, Ninian 1998. The World's Religions. Second Edition. Cambridge, UK: Cambridge University Press. 
Soom, Kaido 2012. Eestimaalase kuvand ristiusust, kirikust ja kristlastest. Jõks, Eerik (toim). Astu alla rahva hulka. Artikleid ja arutlusi Eesti elanikkonna vaimulaadist. Tallinn: Eesti Kirikute Nõukogu, lk 249-270.

Stamoolis, James J. 1986. Eastern Orthodox Mission Theology Today. Marynoll, NY: Orbis, Wipf and Stock Publishers.

Stark, Rodney \& Glock, Charles Y. 1969. Dimensions of Religious Commitment. Robertson, Roland (toim). Sociology of Religion. Middlesex, UK: Penguin Books, lk 253-261.

Stolz, Jörg 2009. Explaining religiosity: towards a unified theoretical model. The British Journal of Sociology 60 (2), lk 345-376 (http://dx.doi.org/10.1111/j.14684446.2009.01234.x).

Ustav, Karp 1908. Pihkwa eestlased. Kirjutanud K. Usstaw. Tartu: Postimehe kirjastus.

\section{Summary}

\section{Centre of Orthodoxy as Seen by Estonian Orthodox: Results of a Qualitative Research}

\section{Liina Eek}

Keywords: antagonism, dimensions of religion, Orthodoxy in Estonia, qualitative research method, religious identity

The article points to the aspects of Orthodoxy that Estonian-language Orthodox regard as essential. The results discussed in the article were obtained in the course of a religious-sociological study. The article presents plenty of citations from interviews, which explain why people consider Orthodoxy as special and different from other confessions. Answers are categorised on the basis of Ninian Smart's classification of the dimensions of religion.

The informants mentioned all the seven dimensions of religion as being in the centre of Orthodoxy: practical and ritual, narrative and mythic, experiential and emotional, social and institutional, ethical and legal, doctrinal and philosophical, and material. The aspects referred to most often were related to experiential and emotional and ritual dimensions. The informants emphasised the experientiality of Orthodoxy, the stability of traditions, and genuine prayer life in comparison with other confessions, which, in combination, makes the Orthodox feel cosy and homelike. Orthodoxy is seen as consistent and all-embracing, enabling freedom of thought and action. The absence of a strict application of the canons of the church (oikonomia) inherent in Orthodoxy tends to be used as an excuse, to ignore the rules that seem to be unpleasant. The phenomena associated with the material dimension were also mentioned rather often. The philosophical dimension was more important for the clergy and those who had studied theology. The narrative dimension, especially the narrative about the arrival of Orthodoxy, occupied a central place among the Setomaa Orthodox. The ethical dimension in association with 
Christian love was mentioned more often than in connection with other ethical aspects, which were rather exceptional cases. Regarding the institutional dimension as the centre of Orthodoxy was also rather exceptional. The article also discusses shaping of the opinion about Orthodoxy, its connection to religious identity, and the role of opposition to other confessions therein. 